\title{
IMPLEMENTASI PEMBELAJARAN BAHASA INDONESIA BERBASIS TEKS DI SMA NEGERI 1 BENGKULU TENGAH KELAS XI
}

\author{
Purnama Sari Vidya Dharma, Ria Ariesta, dan Agus Joko Purwadi \\ Program Studi Pendidikan Bahasa Indonesia \\ Jurusan Pendidikan Bahasa dan Seni \\ FKIP Universitas Bengkulu \\ spurnama597@gmail.com
}

\begin{abstract}
Abstrak
Tujuan penelitian ini untuk mendeskripsikan pelaksanaan pembelajaran berbasis teks di kelas XI IPS dan IPA di SMA Negeri 1 Bengkulu Tengah pada pembelajaran Bahasa Indonesia. Penelitian ini menggunakan metode deskripsi dengan pendekatan kualitatif. Sumber data adalah dua guru Bahasa Indonesia yang mengajar di kelas XI IPS 4, IPS 5, IPA 3, IPA 4, dan siswa. Teknik pengumpulan data dilakukan dengan validasi data. Instrumen yang digunakan berupa lembar observasi perencanaan, dan pelaksanaan. Guru mambuat rancangan pembelajaran sebelum pelaksanaan pembelajaran berlangsung, yaitu RPP. Hasil penelitian tentang perencanaan pembelajaran berbasis teks dari dua RPP yang dibuat guru, keduanya sudah mengambarkan langkah pembelajaran berbasis teks dengan kegiatan pembelajaran. Hasil pelaksanaan pembelajaran berbasis teks menunjukkan bahwa dari keempat tahap pembelajaran berbasis teks, satu tahap tidak dilaksanakan yaitu langkah membangun teks secara mandiri. Alokasi waktu perencanaan pembelajaran kurang sesuai dengan alokasi waktu pelaksanaan pembelajaran berbasis teks. Jam belajar yang singkat dan adanya kegiatan sekolah berdampak pada pelaksanaan pembelajaran berbasis teks dilaksanakan kurang efektif. Hasil penilaian guru terhadap siswa menunjukkan selama proses implementasi pembelajaran berbasis teks yang dilakukan tercapai.
\end{abstract}

Kata kunci : implementasi, pembelajaran, berbasis teks.

\begin{abstract}
The purpose of this study WAS to describe the implementation of text-based learning in class XI IPS and Natural Sciences at SMA Negeri 1 Bengkulu Tengah in learning Indonesian. This study uses a description method with a qualitative approach. The data sources was two Indonesian language teachers who teach in class XI IPS 4, IPS 5, IPA 3, IPA 4, and students. Data collection techniques are done by data validation. The instruments used are in the from of observation sheets planing, and implementation. The teacher makes the learning design before the implementation of learning takes place, namely RPP. The results of reseatch on text-based learning planning from two RPP made by the teacher, both of which have described the steps of text-based learning activities. The results of implementation of text-based learning show that from the four stages of text-based learning, one step is not implementation, namely the step of building text-based learning independently. The allocation of lerning planning time is not accordance with the time allocation for implementation text- based
\end{abstract}


learning. Short study hours and the existence of school activities have an impact on implementing text-based learning implemented less effectively. The results of teacher's assessment of student indicate that during the implementation process the text-based learning is achieved.

\section{Keywords: Implementation, learning, text-based.}

\section{PENDAHULUAN}

Kurikulum 2013 adalah kurikulum baru yang di dalamnya mengutamakan pendidikan karakter, pengetahuan, dan keterampilan. Hal ini tampak dari kompetensi inti (KI) yang merupakan penjabaran dari standar kompetensi lulusan (SKL) yang dibuat untuk mencapai standar kompetensi yang harus dimiliki siswa untuk menyelesaikan jenjang pendidikan.

Pembelajaran merupakan proses yang dilakukan peserta didik dan pendidik baik itu secara individu maupun dalam sebuah kelompok untuk memperoleh pengetahuan serta keterampilan dengan memperhatikan lingkungan. Mata pelajaran Bahasa Indonesia dalam Kurikulum 2013 yang menekankan pentingnya kompetensi sikap, pengetahuan, dan keterampilan, pada kemampuan berbahasa siswa dibentuk melalui pembelajaran berbasis teks secara berkelanjutan.

Hal ini dilihat dari proses pembelajaran yang diawali dengan pengetahuan tentang jenis teks, dilanjutkan dengan kaidah kebahasaan, kemudian keterampilan dalam menyajikan suatu teks tulis dan lisan. Tujuan umum pendidikan dan pengajaran Bahasa Indonesia di lembaga-lembaga pendidikan menurut Hidayat (2001:4-5) adalah memantapkan kedudukan dan fungsi Bahasa Indonesia.

Fadlillah (2014:172) mendefinisikan pembelajaran secara umum yaitu proses interaksi antara pendidik dengan peserta didik maupun antara-peserta didik. Pembelajaran berbasis teks merupakan kegiatan belajar mengajar yang dilakukan sesuai dengan teks yang diajarkan. Pada pembelajaran berbasis teks di kelas, siswa dituntut untuk memahami setiap jenis teks kemudian mendemonstrasi struktur isi dan bahasanya.

Priyatni (2014:41) pembelajaran berbasis teks mendorong pembelajar untuk membaca dan membaca. Pada pembelajaran berbasis teks di kelas, siswa dituntut untuk memahami setiap jenis teks kemudian mendemonstrasi struktur isi dan bahasanya. Mahsun (2014:124) menyatakan menyusun teks merupakan suatu kegiatan yang kompleks yang membutuhkan aktivitas yang teratur (sistematiss), terkontrol, empirik, dan ktiris. Mata pelajaran Bahasa Indonesia dalam Kurikulum 2013 yang menekankan pentingnya kompetensi sikap, pengetahuan, dan keterampilan, pada kemampuan berbahasa siswa dibentuk melalui pembelajaran berbasis teks secara berkelanjutan. Hal ini dilihat dari proses pembelajaran yang diawali dengan pengetahuan tentang jenis teks, dilanjutkan dengan kaidah kebahasaan, kemudian keterampilan dalam menyajikan suatu teks tulis dan lisan. Selama proses pembelajaran ini berlangsung, guru dapat membentuk pengetahuan, keterampilan, dan sikap siswa.

Konteks sosial dan konteks budaya dalam kehidupan sosial memiliki pengaruh satu sama lain terhadap keberagaman wujud teks. Mahsun (2014:1) mengatakan 
bahwa keberagaman teks dengan struktur teks yang beragam pula digunakan untuk keperluannya tersendiri. Bahasa yang digunakan dengan tujuan sosial tertentu itulah yang melahirkan teks.

Teks dapat dikelompokkan menjadi dua kategori besar (genre), yaitu genre sastra dan genre faktual. Genre sastra bertujuan untuk mengajukan emosi dan imajinasi pembaca/ penyimak. Genre sastra dikelompokkan menjadi tiga jenis yaitu teks naratif (novel, cerpen), puitik, dan dramatik. Genre faktual menghadirkan informasi/ gagasan dan bertujuan untuk menggambarkan, menceritakan, atau meyakinkan pembaca/ penyimak (Anderson dalam Priyatni, 2014:66-67).

Priyatni (2014:65) berpendapat teks adalah proses sosial yang berorientasi pada tujuan sosial tertentu dan dalam konteks situasi tertentu pula. Setiap jenjang pendidikan memiliki jenis teks dan tingkat kesukaran yang berbeda sesuai tingkatannya.Pada jenjang Sekolah Menengah Atas (SMA) yang dimuat Permendikbud No. 69 tahun 2013 (dalam Priyatni, 2014:68) terdapat 15 jenis teks.

Hal penting dalam tahapan pembelajaran jangan membawa siswa langsung pada pokok pembahasan teks model tanpa upaya menciptakan kondisi perantara. Pada tahap pertama kegiatan kegiatan membangun konteks dengan memberikan pengetahuan dasar terlebih dahulu kepada peserta didik dan dilanjutkan dengan tahap pemodelan teks.

Guru mengenalkan nilai, tujuan sosial, struktur, serta ciri-ciri bentuk, termasuk ciri kebahasaan yang menjadi penanda teks yang akan diajarkan. Tahap kedua adalah kerja sama membangun teks. Kegiatannya dapat mencakup kegiatan membangun nilai, sikap, dan keterampilan melalui teks yang utuh secara bersamasama. Tahap terakhir membangun teks secara mandiri.
Menurut Suwarna (2006:35) kegiatan pembelajaran sebagai suatu sistem yang memiliki bagian-bagian dan fungsi masingmasing untuk mencapai tujuan pembelajaran yang telah dirumuskan. Dengan begitu penting bagi guru untuk membuat rancangan kegiatan pembelajaran agar tujuan pembelajaran dapat tercapai.

\section{METODE}

Penelitian ini menggunakan metode penelitian deskriptif kualitatif yang mendeskripsikan pembelajaran Bahasa Indonesia berbasis teks di kelas XI IPS dan IPA di SMA Negeri 1 Talang Empat Bengkulu Tengah Tahun Ajaran 2017/2018. Waktu penelitian dilakukan pada pada semester genap tahun ajaran 2017/2018 dari tanggal 2 April hingga 30 April 2018.

Data pada penelitian ini berupa hasil observsi, rekaman, wawancara, dokumentsi yang diambil dari RPP yang guru gunakan, aktivitas belajar di kelas, informasi yang guru berikan, dan informasi dari hasil dokumentsi yang peneliti peroleh.

Sumber data penelitian ini yaitu dua guru Bahasa Indonesia, siswa, dan dokumentasi. Teknik pengumpulan data yang digunakan yaitu validasi data yang diperoleh dari hasil triangulasi data. Instrumen yang digunakan berupa lembar observasi dengan aspek perencanaan, pelaksanaan, dan alokasi waktu.

Peneliti ini menggunakan validasi data dengan cara melakukan triangulasi sumber melalui wawancara pada guru mata pelajaran Bahasa Indonesia yang mengajar di kelas XI IPS dan IPA. Pada metode/ teknik, peneliti melakukan pengecekan data kepada narasumber (guru) dengan cara peneliti menanyakan kepada narasumber (guru) mengenai data yang telah peneliti peroleh dari hasil observasi dan dokumentasi. 
Peneliti sebagai human instrument, berfungsi sebagai penetap fokus penelitian, memilih informan, melakukan pengumpulan data, melakukan analisis, menafsirkan data serta membuat kesimpulan. Kisi-kisi observasi yang digunakan dalam penelitian ini diambil dari aspek RPP berupa aspek perencanaan, pelaksanaan, pemodelan teks dan alokasi waktu.

\section{HASIL DAN PEMBAHASAN Hasil}

Kegiatan pembelajaran Bahasa Indonesia di kelas XI IPS dan IPA dilakukan dengan panduan pembelajaran berupa Rancangan Pelaksaan Pembelajaran (RPP). Implementasi pembelajaran berbasis teks dengan menggunakan pendekatan saintifik dan metode discovery learning. pada perencanaan pembelajaran yang guru buat tidak tergambar pendekatan dan metode yang dipilih dalam langkah pembelajaran yang dibuat.

Pembelajaran adalah serangkaian proses yang dilakukan guru agar siswa belajar. Dari sudut pandang siswa, pembelajaran merupakan proses yang berisi seperangkat aktivitas yang dilakukan siswa untuk mencapai tujuan belajar (Abidin, 2013:3). Ada empat tahapan pembelajaran menurut Mahsun (2014:113) yaitu membangun konteks, pemodelan, kerja sama pengembangkan teks, dan mengembangkan teks secara mandiri. Kegiatan membangun konteks dan pemodelan teks dapat dilakukan secara bersamaan.

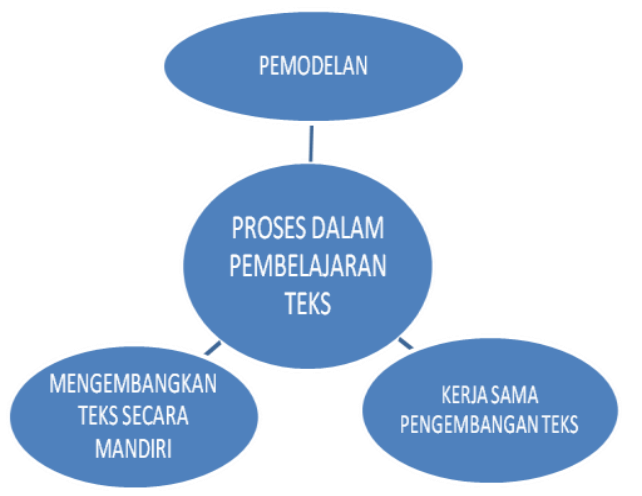

Tahapan pembelajaran berbasis teks (Mahsun, 2014:113)

Menurut Priyatni (2014:98) dalam pembelajran bahasa Indonesia, setiap peserta didik wajib mencoba menyusun teks sesuai dengan struktur isi dan ciri bahasa dari tiap-tiap jenis teks atau sekedar mencoba mencari teks yang memiliki kesamaan dari segi struktur isi atau ciri bahasanya. Kegiatan ini akan memperkuat pemahaman peserta didik terhadap konsep yang telah dipelajari.

Perencanaan pembelajaran berbasis teks yang disusun guru sebagai rancangan proses pembelajaran yang akan dilaksanakan disusun dan disesuaikan dengan materi yang akan dipelajari serta disesuaikan dengan kondisi. Pembelajaran karya ilmiah dan bermain peran yang akan diajarkan kepada siswa, dibuat dengan rancangan kegiatan pembelajaran yang sesuai dengan keadaan peserta didik.

Pada rancangan kegiatan pendahuluan pembelajaran membangun konteks di kelas XI IPS dan XI IPA, langkah pertama peserta didik merespon salam dan berdoa menurut kepercayaan masingmasing untuk menanamkan nilai karakter peserta didik. Peserta didik menerima informasi materi yang akan dipelajari. Peserta didik dibagi ke dalam beberapa kelompok, dengan jumlah anggota setiap kelompok 4-6 orang untuk membentuk nilai karakter kolaborasi dan tangung jawab siswa.

Perencanaan pada tahap pemodelan di kelas XI IPS dan XI IPA pada kegiatan inti, peserta didik membaca 2 atau 3 teks yang bertema sama. Peserta didik mencermati struktur dari 2 atau 3 teks karya ilmiah yang telah dibacanya. Peserta didik mencermati informasi, tujuan, dan esensi teks karya ilmiah yang telah dibacanya. Peserta didik menyajikan hasil diskusi rancangan teks karya ilmiah bersama teman kelompok. 
Pada perencanaan pembelajaran menyusun teks secara berkelompok di kelas XI IPS dan XI IPA. Peserta didik dibimbing oleh guru membuat rancangan karya ilmiah dengan memperhatikan informasi, tujuan, dan esensi karya ilmiah bersama teman kelompok. setelah itu membuat rancangan karya ilmiah dengan memperhatikan informasi, tujuan, dan esensi karya ilmiah bersama teman kelompok.

Pada materi bermain peran peserta didik dibimbing guru berdiskusi dalam kelompok untuk menentukan teks drama yang akan di tampilkan. Peserta didik menyusun rancangan pementasan dengan memperhatikan teknik, langkah-langkah pementasan drama, isi dan kebahasaan teks drama.

Perencanaan kegiatan penyusunan teks secara mandiri di kelas XI IPS dan XI IPA, peserta didik menyusun teks karya ilmiah dengan memperhatikan struktur dan kaidah kebahasaan. Peserta didik menyusun teks karya ilmiah dengan memperhatikan isi, tujuan dan esensi teks karya ilmiah. Untuk kegiatan pembelajaran bermain peran secara mandiri di kelas, dengan memperhatikan teknik dan langkah-langkah pada pementasan drama. Peserta didik dibimbing menyimpulkan ciri kebahasaan teks drama dan menyimpulkan isi pokok dari 2 atau 3 teks drama. Peserta didik memasukkan lembar coretan kerja dan semua draf hingga draf final ke bundel portofolio masing-masing.

Pelaksanaannya di kelas IPA dan IPS tidak sepenuhnya dilaksanakan. Kelas IPA dengan materi bermain peran lebih berfokus pada kegiatan mengkomunikasikan dengan cara siswa menerima materi kemudian mendemonstrasikan. Sedangkan kelas IPS materi karya ilmiah melaksankan kegiatan mengkomunikasikan dan mencoba, tetapi tidak efektif.
Tahap pertama pelaksanaan pembelajaran membangun konteks di kelas IPA, guru awali dengan memberi tahu tentang materi yang akan dipelajari secara garis besar. Guru tidak langsung mengunakan teks diawal kegiatan pembelajaran. Guru membuka wawasan siswa terlebih dahulu dengan menannyakan drama apa yang sudah pernah siswa baca atau tonton.

Pada pertemuan berikutnya tahap pemodelan teks guru melakukan tanya jawab materi pertemuan sebelumnya dan menyampaikan materi yang akan dipelajari. Setelah memberi penjelasan materi dari pengertian dan struktur teks guru mengaitkan teks yang telah dibaca oleh siswa dengan judul "Panembahan Reso" dengan kegiatan siswa. Siswa membaca dan memerankan salah satu tokoh dalam drama sesuai dengan kegiatan pembelajaran pada RPP.

Tahap penyusunan teks secara berkelompok di kelas XI IPA guru membentuk kelompok dengan siswa menentukan sendiri kelompoknya. Setelah duduk bersama teman kelompok, guru meminta setiap kelompok untuk berlatih kemudian mementaskannya dan membahasnya bersama-sama. Guru tidak melaksanakan kegiatan menyusun teks drama baik secara berkelompok maupun secara mandiri.

Pada kelas IPS kegiatan membangun konteks, guru memulai dengan menjelaskan materi pelajaran terlebih dahulu setelah memberi tahu materi apa saja yang akan dipelajari pada pertemuan itu. Guru tidak langsung menggunakan teks sesuai RPP pada awal pelajaran, guru mengaitkan materi karya ilmiah terlebih dahulu dengan materi proposal yang sudah dipelajari kemudian guru memberikan pengetahuan kepada siswa. 
Dengan mengaitkan kedua materi tersebut guru membangkitkan ingatan siswa tentang materi proposal yang merupakan bagian dari karya ilmiah. Siswa membaca contoh teks setelah mendapatkan materi pelajaran. Guru memanfaatkan contoh teks ketika membangun konteks agar siswa lebih mudah memahami penjelasan.

Pada tahap pemodelan di kelas IPS materi karya ilmiah, guru menggunakan teks yang ada pada buku pelajaran dengan judul teks "Kasus Mencuri Sandal". Karena kurangnya alat dan media untuk menampilkan teks, guru hanya menggunakan teks pada buku sebagai media belajar. Tahap menyusun teks secara berkelompok dikerjakan oleh siswa bersama teman kelompok sebagai tugas proyek karena jam pelajaran sudah berakhir. Tahap pembelajaran menyusun teks secara mandiri tidak dilaksankan oleh guru dan siswa.

Hal penting dalam pembelajaran berbasis teks adalah kemampuan siswa menghasilkan teks yang berkaitan dengan penilaian keterampilan siswa. Berdasarkan hasil penelitian menunjukkan bahwa pelaksanaan pembelajaran berbasis teks dilakukan masih kurang sesuai dengan tahapan pembelajaran berbasis teks.

\section{Penilaian}

implementasi

pembelajaran berbasis teks dilakukan secara autentik yang merupakan penilaian kinerja yang meminta peserta didik untuk mendemonstrasikan keterampilan dan kompetensi tertentu sebagai refleksi dari pengetahuan yang dikuasainya (Mahsun, 2014:150). Dilihat dari hasil pembelajaran yang dilakukan oleh kedua guru berdasarkan rancangan pembelajaran yang dibuat dengan pelaksanaannya tidak sepenuhnya sesuai dengan rancangan.

Tetapi pada hasil penilaian belajar siswa dapat dikatakan jika pelaksanaan pembelajaran berbasis teks di kelas XI IPA dan IPS sudah berhasil. Hal ini dilihat pada hasil nilai rata-rata siswa di atas KKM. Meskipun untuk jam pelajaran guru menyesuaikan materi pelajaran dengan alokasi waktu jam pelajaran yaitu $2 \times 45$ menit setiap pertemuannya.

Kurang efektifnya pelaksanaan

pembelajaran sesuai rancangan pembelajaran kuran sesuai, hal ini dikarenakan alokasi waktu yang digunakan guru kurang sesuai dengan pelaksanaannya. Guru memberikan penjelasan materi dan pemodelan teks selama proses belajar tanpa menerapkan ke tahap menyusun teks. Penilaian dilakukan secara autentik dengan cara melakukan penilaian kinerja peserta didik ketika mendemonstrasikan keterampilannya di depan kelas. Guru juga menggunakan jam pelajaran untuk mengoreksi tugas siswa pada materi sebelumnya.

Dengan begitu penting bagi siswa untuk belajar secara mandiri, agar pengetahuan dan keterampilan yang sudah diketahui dapat diterapkan langsung dalam bentuk teks karya ilmiah dan teks drama. Jika siswa belajar secara mandiri, siswa akan memiliki pengalaman mencoba dan mengaplikasikan materi pelajaran yang sudah diperolehnya. Agar hasil belajar yang siswa peroleh lengkap sesuai dengan tahapan pembelajaran yang seharusnya siswa peroleh.

\section{Pembahasan}

Pembelajaran adalah serangkaian proses yang dilakukan guru agar siswa belajar. Dari sudut pandang siswa, pembelajaran merupakan proses yang berisi seperangkat aktivitas yang dilakukan siswa untuk mencapai tujuan belajar (Abidin, 2013:3). Pembelajaran berbasis teks yang terdiri dari empat tahap yang harus dilaksanakan sebagai bagian penting dalam pelaksanaan pembelajaran. Keempat tahap itu membangun konteks, pemodelan teks, penyusunan teks secara 
berkelompok, dan penyusunan teks secara mandiri.

Berdasarkan hasil penelitian menunjukkan bahwa pelaksanaan pembelajaran berbasis teks dilakukan masih kurang sesuai dengan tahapan pembelajaran berbasis teks. Hal ini dikarenakan alokasi waktu yang digunakan guru kurang sesuai dengan pelaksanaannya. Guru memberikan penjelasan materi dan pemodelan teks selama proses belajar tanpa menerapkan ke tahap menyusun teks.

Siswa kelas IPA dan IPS yang diteliti, berdasarkan tujuan pembelajarannya yaitu selama pembelajaran siswa mampu merinci atau mengidentifikasi teks yang dipelajari. Pada materi bermain peran tujuan pembelajarannya adalah peserta didik dapat mengidentifikasi alur cerita, babak demi babak, konflik, dan mempraktik salah satu tokoh. Sedangkan pada materi karya ilmiah tujuan pembelajarannya adalah peserta didik dapat mengidentifikasi struktur karya ilmiah, informasi penting yang dipaparkan dalam karya ilmiah, sistematika penulisan, kaidah kebahasaan, dan mengontruksi sebuah karya ilmiah.

Guru membuat rancangan pembelajaran berupa RPP sebagai pedoman proses belajar. Perencanan pelaksanan pembelajaran yang dibuat oleh guru sebelum kegiatan pembelajaran tidak terlaksana sepenuhnya sesuai rancangan. Dalam pembelajaran yang dilakukan di dalam kelas terutama pada langkahlangkah pembelajaran menyusun teks yang dilakukan baik itu dalam bentuk kelompok maupun menyusun teks secara mandiri kurang efektif dilaksanakan.

Pembelajaran efektif menurut Dick \& Reiser (dalam Sutikno, 2009:173) adalah suatu pembelajaran yang memungkinkan siswa untuk belajar keterampilan spresifik, ilmu pengetahuan, dan sikap serta yang membuat siswa senang.

Berdasarkan hasil wawancara pada guru di kelas IPS dan IPA, dapat disimpulkan hambatan yang terjadi selama proses pembelajaran berbasis teks berlangsung. Hambatan implementasi pembelajaran berbasis teks yang terjadi selain dari segi kurangnya waktu pembelajaran, dari siswa yang kurang aktif ketika belajar dan kurang memperhatikan ketika guru menjelaskan materi, sehingga siswa kurang memahami materi yang sedang dipelajari.

Dari segi buku yang digunakan juga menjadi hambatan, sebab sumber belajar yang digunakan hanya satu buku dan guru tidak ada menampilkan contoh teks selain dari buku yang digunakan. Dengan demikian guru tidak dapat melaksanakan semua kegiatan dan langkah pembelajaran sesuai dengan RPP.

Dalam pembelajaran, proses berpikir, sistematis, empirik, dan kritis dalam menerapkan prosedur ilmiah yang berupa pengumpulan data, analisis data, dan penyajian hasil sangatlah penting (Mahsun, 2014:120). Untuk itu, pembelajaran berbasis teks yang didasarkan pada empat tahapan teks bila dilakukan sesuai tahapan yang seharusnya, memerlukan waktu yang banyak sehingga seluruh tahapan pembelajaran dapat terlaksana.

Tahap pertama pelaksanaan pembelajaran membangun konteks di kelas IPA, guru awali dengan memberi tahu tentang materi yang akan dipelajari secara garis besar. Guru tidak langsung mengunakan teks diawal kegiatan pembelajaran.

Guru lebih memberikan pemahaman terlebih dahulu kepada siswa sebelum melihat langsung contohnya.

Pada pertemuan berikutnya tahap pemodelan teks guru melakukan tanya 
jawab materi pertemuan berikutnya dan menyampaikan materi yang akan dipelajari. Pada tahap penyusunan teks secara berkelompok di kelas XI IPA guru membentuk kelompok dengan siswa menentukan sendiri kelompoknya. Setelah duduk bersama teman kelompok, guru meminta setiap kelompok untuk berlatih kemudian mementaskannya dan membahasnya bersama-sama.

Dalam kegiatan kelompok ini guru tidak ada mengajarkan untuk menyusun teks secara berkelompok. Guru lebih menekankan pada keterampilan siswa dalam membawakan sebuah naskah drama. Tahap menyusun teks secara mandiri tidak guru lakukan, sebab waktu yang dibutuhkan siswa untuk membuat sebuah teks drama tidak singkat.

Pada kelas IPS guru menjelaskan materi pelajaran terlebih dahulu setelah memberi tahu materi apa saja yang akan dipelajari pada pertemuan itu. Guru tidak langsung menggunakan teks sesuai RPP pada awal pelajaran, guru mengaitkan materi karya ilmiah terlebih dahulu dengan materi proposal yang sudah dipelajari kemudian guru memberikan pengetahuan kepada siswa.

Dengan mengaitkan kedua materi tersebut guru membangkitkan ingatan siswa tentang materi proposal yang merupakan bagian dari karya ilmiah. Setelah itu guru meminta siswa untuk membaca contoh teks setelah mendapatkan materi pelajaran. Tindak lanjut yang guru lakukan setelah membangun konteks adalah pemodelan teks.

Guru menjelaskan secara singkat struktur yang membangun teks tersebut dan meminta siswa menunjukkan bagianbagiannya pada teks. Pertemuan selanjutnya pada tahap menyusun teks secara berkelompok yang ditentukan oleh siswa itu sendiri. Guru meminta siswa untuk membuka buku untuk mengerjakan tugas bersama teman kelompok. Tugas tersebut guru jadikan tugas proyek sebab waktu pelajaran sudah habis.

Tahap akhir dari pembelajaran berbasis teks di RPP pada kelas IPS yaitu menyusun teks secara mandiri. Pada penerapannya di kelas IPS guru tidak bisa melaksanakannya dikarenakan keterbatasan waktu, media dan alat untuk membuat karya ilmiah disekolah. Siswa tidak akan bisa menyelesaikan tugas membuat karya ilmiah jika dilakukan di sekolah dengan jam belajar $2 \times 45$ menit.

Berdasarkan hasil wawancara yang dilakukan pada guru di kelas IPA tentang pelaksanaan pembelajaran yang tidak sesuai dengan rancangan. Dapat disimpulkan jika implementasi pembelajaran tidak sesuai dengan rancangan yang seharusnya dilakukan, guru mengalihkan kegiatan pembelajaran. Guru mengalihkan pembelajran misalnya seperti pada saat mendemonstrasikan atau mementaskan sebuah drama.

Untuk membuat sebuah pementasan dibutuhkan biaya dan peralatan dan waktu yang lama, karena waktunya tidak memungkinkan dilaksanakan di sebuah panggung, maka guru mengalihkan tempat pementasannya di kelas saja dan tetap menggunakan teks. Siswa tidak menghafal naskah, artinya mereka tetap memegang teks ketika melakukan pementasan. Ketercapaian pengambilan nilainya praktiknya tetap ada karena mereka sudah menampilkan dan sudah bermain drama dengan baik.

Hambatan implementasi pembelajaran berbasis teks yang terjadi selain dari segi kurangnya waktu pembelajaran, dari siswa yang kurang aktif ketika belajar dan kurang memperhatikan ketika guru menjelaskan materi, sehingga siswa kurang memahami materi yang sedang dipelajari.

Dari segi buku yang digunakan juga menjadi hambatan dalam pembelajaran 
berbasis teks, sebab sumber belajar yang digunakan hanya satu buku dan guru tidak ada menampilkan contoh teks selain dari buku yang digunakan. Dengan demikian guru tidak dapat melaksanakan semua kegiatan dan langkah pembelajaran sesuai dengan RPP.

\section{PENUTUP}

\section{Kesimpulan}

1. Perencanaan pelaksanaan pembelajaran bahasa Indonesia berbasis teks yang dibuat guru kelas XI IPS dan IPA terdiri atas empat tahap yaitu membangun konteks, pemodelan teks, menyusun teks secara berkelompok, dan menyusun teks secara mandiri.

2. Pada langkah pembelajaran yang dibuat guru belum menggambarkan pembelajaran berbasis teks.

3. Pelaksanaan pembelajaran bahasa Indonesia berbasis teks yang dilakukan guru di kelas XI IPS dan IPA tidak sepenuhnya terlaksana sesuai dengan rancangan.

4. Hasil penilaian guru terhadap siswa menunjukkan bahwa pembelajaran yang dilakukan tercapai.

\section{Saran}

1. Pembelajaran berbasis teks di buat dengan tujuan penggunaan Bahasa
Indonesia di sekolah dapat diterapkan oleh siswa dan guru.

2. Implementasi pembelajaran menyusun teks sebaiknya memenuhi keempat tahapan pembelajaran teks yaitu membangun konteks, pemodelan, penyusunan teks secara kelompok, dan penyusunan teks secara mandiri.

3. Penggunaan bahasa Indonesia ketika proses pembelajaran sedang berlangsung seharusnya diterapkan oleh guru dan siswa.

\section{DAFTAR PUSTAKA}

Abidin, Yunus. 2013. Pembelajaran Bahasa Berbasis Pendidikan Karakter. Bandung: PT Refika Aditama.

Fadlillah. 2014. Implementasi Kurikulum 2013. Yogyakarta: Ar-Ruzz Media.

Hidayat, Kosadi. 2001. Perencanaan Pengajaran Bahasa Indonesia. Bandung: Trimitra Mandiri.

Mahsun. 2014. Teks Dalam Pembelajaran Bahasa Indonesia. Jakarta: PT. Raja Grafindo Persada.

Priyatni, Endah Tri. 2014. Desain Pembelajaran Bahasa Indonesia dalam Kurikulum 2013. Jakarta: Bumi Aksara.

Sutikno, Sobry. 2009. Belajar dan Pembelajaran. Bandung: Prospect. 